\title{
Mental health and school life in Durango Parents' perspective
}

\section{La salud mental y la convivencia escolar en Durango Perspectiva de los padres de familia}

LARA-ESQUEDA, Agustin $\dagger^{1-2}$, CEJAS-LEYVA, Luz María*1 ${ }^{1}$, HERRERA-VARGAS, Isela Vanessa ${ }^{1}$ and LARA-BASULTO, Agustin David ${ }^{2}$

${ }^{I}$ Facultad de Psicología y Terapia de la Comunicación Humana, UJED

${ }^{2}$ Consultoría LARBAS SA de CV

ID $1^{\text {st }}$ Author: Agustin, Lara-Esqueda / ORC ID: 0000-0002-2837-4915, Researcher ID Thomson: AAX-7843-2021, CVU CONACYT ID: 271388

ID $1^{\text {st }}$ Co-author: Luz, María, Cejas-Leyva / ORC ID: 0000-0003-1822-5606, Researcher ID Thomson: V-3185-2019, CVU CONACYT ID: 889382

ID $2^{\text {nd }}$ Co-author: Isela Vanessa, Herrera-Vargas / ORC ID: 0000-0002-9154-6978, Researcher ID Thomson: X-33142018, CVU CONACYT ID: 954357

ID $3^{\text {rd }}$ Co-author: Agustin David, Lara-Basulto / ORC ID: 0000-0002-4533-8019, Researcher ID Thomson: C-3251-2018, CVU CONACYT ID: 800273

DOI: $10.35429 / J P D .2021 .14 .5 .19 .31$

Received July 25, 2021; Accepted December 30, 2021

\begin{abstract}
Objective: Identify the effects of the National School Coexistence Program on mental health in parents of primary and secondary education students, applied in the 2020-2021 school year, a period characterized by confinement caused by COVID-19. Methodology: research carried out by an exploratory, non-experimental, observational and cross-sectional survey with descriptive statistical analysis. A non-probabilistic sampling was used by accident and convenience, selected with $95 \%$ reliability. To carry out the present investigation, the questionnaires, GAD7, PHQ9 and Burnout of ShiromMelamed Burnout were used, for the statistical analysis of the characteristics of the studied population, measures of central tendency and dispersion were used. Contribution: significant data are presented on the emotional well-being of parental figures, during the 2020-2021 school year, in which educational institutions worked online due to COVID-19 and the National School Coexistence Program was applied.
\end{abstract}

Mental health, Parental figures, Emotional state

\begin{abstract}
Resumen
Objetivo: Identificar los efectos del Programa Nacional de Convivencia Escolar en la salud mental en los padres de alumnos de educación primaria y secundaria, aplicado en el ciclo escolar 2020-2021, período caracterizado por el confinamiento causado por el COVID-19. Metodología: investigación efectuada por encuesta de tipo exploratoria, no experimental, observacional y transversal con análisis estadístico descriptivo. Se utilizó un muestreo no probabilístico por accidente $\mathrm{y}$ conveniencia, seleccionada con un $95 \%$ de confiabilidad. Para la realización de la presente investigación se utilizaron los cuestionarios, GAD7, PHQ9 y Burnout de Shirom-Melamed Burnout, para el análisis estadístico de las características de la población estudiada se emplearon medidas de tendencia central y dispersión. Contribución: se presentan datos significativos sobre el bienestar emocional de las figuras parentales, durante el ciclo escolar 2020-2021, en el que las instituciones educativas laboraron en línea a causa del COVID-19 y se aplicó el Programa Nacional de Convivencia Escolar.
\end{abstract}

Salud mental, Figuras parentales, Estado emocional

Citation: LARA-ESQUEDA, Agustin, CEJAS-LEYVA, Luz María, HERRERA-VARGAS, Isela Vanessa and LARABASULTO, Agustin David. Mental health and school life in Durango Parents' perspective. Journal Practical Didactics. 2021, 5-14: 19-31

\footnotetext{
*Correspondence to Author (e-mail: doctoradoluz1 @ hotmail.com)

$\uparrow$ Researcher contributing as first author.
} 


\section{Introduction}

Beyond the absence of mental disorders, mental health is related to a state of complete physical, mental and social well-being, through which people can cope with the normal stress of everyday life (WHO, 2004).

In this sense, school coexistence as a Mexican educational policy seeks to strengthen both in the students and in their families aspects that support the adequate development of the child's mental health (WHO, 2004).

With the National School Coexistence Program (PNCE), the federal government proposes a comprehensive intervention to strengthen the educational community (students, teachers and parents) through the development of social and emotional skills in order to provide them with the necessary resources to face the challenges of daily life. Face the challenges posed by daily life, emphasizing the work with mothers, fathers and guardians (SEP, 2018).

The present study integrates the results obtained with the application of the GAD7 and PHQ9 questionnaires to parents of elementary and high school students benefited by the program in question, in order to identify the effects of this, on the aforementioned actors; during the 2020-2021 school year, a period characterized by the confinement caused by COVID-19.

\section{Justification}

Mental health is an important pillar for the general wellbeing of the members of any community, therefore, it is as important as health and physical wellbeing. Its conscious promotion of rewarding emotional relationships and positive emotional expressions of coping in adults (WHO, 2004).

With programs such as the PNCE, which involves in actions for the development of socioemotional skills in mothers, fathers and guardians, conditions are put in place that promote respectful coexistence in the educational community (SEP, 2018).
Therefore, with programs such as the aforementioned, it is possible to develop confidence to express emotions and feelings in a respectful manner, with positive weighting on the participation of mothers and fathers (SEP, 2019).

\section{Problem}

Mental health problems can affect each and every one of the members of society; therefore, their strengthening constitutes a challenge for the development of proposals that contribute to their emotional well-being (WHO, 2004). In conditions such as those currently detected, in which the lack of social and emotional skills has been related to a wide variety of anxiety and mood disorders, among other emotional conditions (SEP, 2018), it becomes necessary to develop skills for self-regulation, to avoid behaviors related to impulses, to avoid unassertive expressions of emotions and for the positive coping of conflicts (SEP, 2019).

\section{Objective}

To identify the effects of the National School Coexistence Program on mental health in parents of elementary and high school students, applied in the 2020-2021 school year, a period characterized by the confinement caused by COVID-19.

\section{Theoretical framework}

The theoretical references related to mental health and school coexistence, as well as the parents' perspective on the subject, are presented below.

\section{National School Coexistence Program}

Education in Mexico should contribute to a better human coexistence. Within the framework of this constitutional mandate, the Government of the Republic has implemented the National Policy for a School Free of Bullying. Derived from it, the Ministry of Public Education, through the Undersecretary of Basic Education, promotes the National Program for School Coexistence (PNCE), which has the purpose of favoring the development of peaceful school environments. In this task, the teacher's activity is a fundamental factor for children to learn to coexist (Odalk, et al., 2016). 
The PNCE is an initiative that the Federal Government has undertaken through the Secretariat of Public Objective Education (SEP), to promote favorable relationship and coexistence environments for teaching and learning, in basic education schools. It is also part of the National Policy for a Bullying-Free School, which proposes a formative and preventive strategy for the personal strengthening of students in the following aspects:

1. The development of social and emotional skills.

2. The expression and management of emotions in a respectful manner.

3. Conflict resolution through dialogue and the search for agreements.

This is an intervention proposal of an experiential nature, so that the school learns to live together through classroom activities, with the support of educational materials (SEP., 2017). Similarly, it promotes the participation of the school community in this process, mainly managers, mothers, fathers and tutors, as an integral and inclusive action to improve coexistence from the family environment, which contributes to establish harmonious, peaceful and inclusive relationships between students, teachers, mothers and fathers, at the same time as between staff with management functions and support staff (Díaz, García, \& Legañoa, 2018).

This proposal has its origin and experience in two years of work as a Project in favor of School Coexistence (PACE): first in 18 500 schools of the Full-Time Schools Program, during the 2014-2015 school year and subsequently, it was implemented in 35000 schools of the Full-Time Schools Program and the Safe School Program, in the 2015-2016 school year; in both cases, only in third grade of elementary education.

Based on the experience and in order to meet the needs detected in schools, the Undersecretary of Basic Education (SEB) proposes a process of evolution of the PNCE coverage in the short and medium terms towards 2018, considering the advances in the Educational Reform, as well as the definition of the Curricular Proposal and the new Educational Model.
In this context, during the 2016-2017 school year, the National School Coexistence Program was made official, with a coverage of attention from first to sixth grades in public elementary schools and with educational support materials for teachers, students and families (PNCE, 2021).

\section{Background}

The PNCE has its antecedent in the Project for School Coexistence (PACE), which began in the 2014-2015 school year, with the participation of 18,500 full-time elementary schools. The objective of PACE in these two stages was to promote the creation of harmonious, peaceful and inclusive school coexistence environments, to promote the improvement of educational quality and contribute to prevent bullying situations.

PACE reached 1,325,014 students in third grade of primary education and 49,104 participating teachers. The main actions of PACE were:

- Training to State Technical Teams (ETE) in the topics of self-esteem, emotion management, inclusive coexistence, peaceful conflict resolution, respect for rules, and family communication, as well as the use of educational materials. The technical teams trained supervisors, school principals and classroom teachers.

- $\quad$ Three national meetings were held with ETEs to provide training and information on the implementation of the Project.

- $\quad$ Preparation and distribution of 434,000 copies of the third grade teacher's manuals and 350,000 copies of the work manual. Workshops for mothers, fathers and tutors.

- Preparation of audiovisual materials and design of a website as a resource for dissemination and support to raise awareness, inform and orient teachers, directors, students, mothers and fathers about the contents of PACE and the creation of harmonious, peaceful and inclusive coexistence environments. 
According to a survey of 850 technical pedagogical advisors, supervisors, directors and teachers from different entities, PACE was accepted by the actors of the school community, who participated in the training and in the implementation of the Project. According to their opinions, the materials for third grade are adequate and can be easily used for classroom work (98\%); they can generate favorable changes in students in the classroom (98\%); the Work Manual. Workshops for parents and guardians contribute to improve coexistence in the students' families and facilitate reflection on the six PACE themes (98\%). The implementation as a project during two school cycles allowed recovering lessons learned, through the information shared by the academic heads of the entities, just as it offered solid bases for its generalization in the 20162017 school cycle, as PNCE in all grades of primary education (PNCE, 2021); (Díaz, García, \& Legañoa, 2018).

\section{Fundamentals}

The school climate is one of the variables that most influences student learning (Casassus, Froemel and Palafox, 1998); (Treviño et al., 2010). According to students' perception of school climate, it can be stated that "they learn more when they attend schools where they feel welcomed and where there are cordial and respectful relationships between students and teachers. A good school climate is synonymous with a school with harmonious functioning, where the educational community relates positively" (Treviño, Castro, Costilla, Donoso, \& Valdés, 2010).

The PNCE proposes a comprehensive intervention with formative actions that contribute to strengthening the educational community as a whole, with the coordinated action of state educational authorities. Its emphasis lies in the personal and social strengthening of students, teachers and parents, through the development of social and emotional skills, so that they recognize their own worth, respect themselves and others, express and manage their emotions, resolve conflicts assertively through dialogue and the search for agreements, and become autonomous individuals capable of internalizing rules and respecting them, as well as assertively facing the situations and challenges of daily coexistence (Sánchez, 2018).
The PNCE, is based on the national
regulatory framework, programmatic documents and Federal Government policies on education, which establish the principles and criteria to address the issue and provide support for actions to promote harmonious, inclusive and peaceful coexistence in schools, which will contribute to meeting the national objective of providing quality education that favors learning and the comprehensive development of children and adolescents (CNEPDS., 2018).

From the constitutional framework, Article $3^{\circ}$ establishes the values and criteria that should be sought in the education provided by the State, among which are: "develop harmoniously, all the faculties of the human being" and "contribute to the best human coexistence, in order to strengthen the appreciation and respect for cultural diversity, the dignity of the person, the integrity of the family, the conviction of the general interest of society, the ideals of fraternity and equal rights of all, avoiding privileges of races, religion, groups, sexes or individuals".

The General Law of Education (LGE), in addition to considering the principles and criteria of Article $3^{\circ}$ constitutional, establishes that "Education is a fundamental means to acquire, transmit and increase culture; it is a permanent process that contributes to the development of the individual and the transformation of society, and is a determining factor for the acquisition of knowledge and to form women and men, so that they have a sense of social solidarity" (LGE, Article 2o). (DOF., 2017).

In addition, education must "promote the value of justice, observance of the Law and equality of individuals before it, foster the culture of legality, inclusion and nondiscrimination, peace and non-violence in any type of its manifestations, as well as knowledge of and respect for Human Rights" (LGE, Article $\left.7^{\circ}\right)$. For its part, Article 8 establishes, among other criteria, that education shall be oriented to fight against fanaticism, prejudice, stereotyping, discrimination and violence. 
It also provides that such education "shall contribute to a better human coexistence, both by the elements it provides in order to strengthen in the student, together with the appreciation for the dignity of the person and the integrity of the family, the conviction of the general interest of society, and by the care it takes to support the ideals of fraternity and equal rights of all men, avoiding privileges of race, religion, groups, sexes or individuals". (DOF., 2013).

On the other hand, the National Development Plan 2013-2018 establishes two goals linked to coexistence: "Mexico in peace", which states that the country demands a social coexistence that has as a framework the respect and valuation of plurality; and "Mexico with quality education", which recognizes that in schools there is an increase in group, institutional and contextual violence, which affect the processes of coexistence and teaching and learning (DOF., 2013).

The General Law on the Rights of Children and Adolescents (LGDNNA) establishes that the authorities, within the scope of their respective competencies, are obliged to foster "the culture of respect, promotion and protection of the rights of children and adolescents, based on the guiding principles of this Law", among which are the best interests of the child, substantive equality, nondiscrimination, inclusion, interculturality, the pro-person principle and access to a life free of violence (DOF., 2017).

\section{Objectives of the PNCE with the Rules of Operation in Force.}

The National School Coexistence Program is carried out in Mexico, with the purpose of promoting coexistence environments in schools that favor student learning, in order to comply with the aforementioned, objectives were established in accordance with the Rules of Operation in Force, by the PNCE. Said objectives, are the following:

\section{General Objective:}

To favor the establishment of harmonious and peaceful coexistence environments, which contribute to prevent bullying situations in Basic Education Public Schools, favoring conditions to improve school achievement.

\section{Specific objectives:}

To promote with the support of educational materials the pedagogical intervention of a formative and preventive nature in public basic education schools, aimed at having students recognize their own worth and learn to respect themselves and other people, to express and regulate their emotions, to establish agreements and rules, as well as to manage and resolve conflicts in an assertive manner.

- $\quad$ Encourage the development of technical skills of educational personnel to promote the improvement of healthy and peaceful school coexistence in their schools with the support of educational materials.

- Promote the informed and proactive participation of students' families in public elementary schools, in favor of healthy and peaceful school coexistence. To contribute to the prevention of bullying situations.

Strengthen the Basic System of Educational Improvement in the schools benefiting from the PNCE. (Caso, Osuna, \& Gallegos, 2019).

\section{The family and its influence on school coexistence}

The family as a relevant social institution in the integral formation of the human being constitutes the first educational environment for boys and girls in their socio-personal formation process, since there is a close relationship between people who share feelings, emotions and relationships of intimacy, respect and other essential values to strengthen the integral formation of people in their first years of life.

The education and training given in the family should be oriented towards the formation of an adequate coexistence in order to provide the necessary basis for the resolution of school conflicts that may arise in educational institutions. The current situation of conflicts in school coexistence has led to rethink the role of the family in the education of schoolchildren because there is a direct relationship between the influence it plays in the social formation of the individual and the role of the family in the education of schoolchildren. (Bolaños \& Stuart, 2019).

LARA-ESQUEDA, Agustin, CEJAS-LEYVA, Luz María, HERRERAVARGAS, Isela Vanessa and LARA-BASULTO, Agustin David. Mental health and school life in Durango Parents' perspective. Journal Practical Didactics. 2021 
Thus, the family influences the social formation of those individuals of school age who interact in the socialization processes, since they are the first and the most persistent because they generate, with great importance and repercussion, a positive or negative school coexistence, depending on the degree of integral formation acquired in this social group. Today, this is weakened as a social institution in charge of providing the first knowledge of life and the formation of values necessary for the socialization and coexistence of every human being, because it has been displaced by other elements that develop a wrong orientation in the teaching process of students in educational establishments. (Borrows \& Olivares, 2006.).

A real family structure rich in values and norms, belonging to social groups that value and respect life, and the proper guidance provided to children and students regarding the use of new communication and entertainment technologies contribute to the improvement of the socialization processes that take place in educational establishments, an aspect that is evident in the school coexistence of children throughout their teaching and learning process, which contributes to the formation of useful citizens for the social advancement of a country. (Bolaños \& Stuart, 2019).

\section{Well-being in parents}

An adequate family functioning promotes greater psychological well-being of all members, and acts as a protective factor in the face of difficult situations that must be faced and overcome. Therefore, family functioning may be one of the most influential aspects when facing changes within family systems, to such an extent that they may or may not adapt to new transformations. (Álvarez \& Salazar, 2018).

Similarly, an inadequately functioning family can generate symptoms and illnesses that put the psychological well-being of the children at risk. Therefore, family functioning can be one of the most influential aspects when facing changes within family systems, to the point that they can adapt or not to new transformations, becoming one of the main indicators for an adequate state of health and psychological well-being.
It has been widely reported in research that the presence of depressive symptomatology in mothers decreases their levels of reciprocity, synchrony and coordination with their child, compromising the dyadic and triadic capacity that allows affective regulation. (Feldman, 2007).

Likewise, mothers with high levels of stress report feeling overwhelmed by the demands of their children, being less available to respond to their needs (Rodrigo, Martín, Cabrera, \& Máiquez, 2009).

In families in which one of the parents has a mental illness, the child's development depends more on the level of family functioning than on the dyadic interaction with the parent with a pathology (Seifer \& Dickstein, 2000). This experience also favors emotional regulation in the child during the interaction, contributing to the reduction of tension and stress (Fivaz-Depeursinge and Favez, 2006). For their part, there is some evidence that would indicate that fathers are sensitive to maternal risks, including depressive symptomatology (Cummings, Goeke-Morey, \& Raymond, 2004) and that the father's adequate mental health acts as a protective factor for the child in the relationship between maternal and child depressive symptomatology (Gere, et al., 2013).

The combination of financial pressure, loss of child care and health problems is proving very difficult for families, and mental health problems are expected to increase as a side effect of the current pandemic, secondary to COVID-19 and the measures that have been taken to contain it (Beacons, 2020).

The potential long-term consequences on children due to increased parental stress, anxiety, and depression are still unknown. However, previous research tells us that children exposed to these problems are more likely to suffer mental health problems, in addition to developing possible learning and behavioral problems.

We are currently witnessing an escalation of anxiety and depression in fathers and mothers. Current studies show that pregnant mothers, and those with young children, experience increased symptoms of anxiety and depression. 
A history of mental illness, domestic conflict and financial stress have been associated with poorer mental health in various child age groups. These figures are especially troubling because young children are highly vulnerable to maternal mental illness due to their near total dependence for basic health and safety needs.

The increase in parental mental illness, combined with the fact that children spend more time at home due to COVID-19, present multiple risks, including alterations in children's stress system function, higher rates of physical health problems, and cognitive impairment.

Parental stress associated with mental illness can also lead to negative interactions, including harsh discipline and being less responsive to children's needs. In addition, depression can contribute to aggravated health problems and poor quality of life (Faros, 2020).

Achieving a positive and responsible relationship with stable and protective emotional bonds between adult caregivers and children is very important for the good development of boys and girls. It is of concern that 3 out of 10 caregivers present depression and $5 \%$ of caregivers present signs of distress, anxiety or hopelessness.

\section{Research methodology}

The research conducted was an exploratory, non-experimental, observational and crosssectional survey with descriptive statistical analysis. A non-probabilistic sampling by accident and convenience was used, selected with $95 \%$ reliability. The questionnaires GAD7, PHQ9 and Burnout of Shirom-Melamed Burnout were used to carry out the present research. For the statistical analysis of the characteristics of the studied population, measures of central tendency and dispersion were used.

Sample

A statistically significant sample of 1185 participants (parents from the State of Durango) was defined, which were precisely those analyzed in the final sample. A nonprobabilistic sampling by accident and convenience was used, selected with $95 \%$ reliability.
The criteria used for the selection of the sample were:

- $\quad$ Having a child in primary or secondary education.

- $\quad$ That the school where their child(ren) attend(s) has implemented the National School Coexistence Program.

- $\quad$ To agree to answer the survey.

\section{Procedure}

A total of 1185 parents from the State of Durango with children in primary and secondary school participated voluntarily and anonymously. The questionnaires GAD7, PHQ9 and Burnout of Shirom-Melamed Burnout were applied in order to evaluate the incidence of the National Program of School Coexistence on the mental health of these actors; estimation implemented to be filled in by means of hyperlinks (URL).

Once the information was collected, the data were processed with SPSS version 25 software for statistical analysis where measures of central tendency and dispersion were used to describe the most notable results of each of the sections of the instruments used.

\section{Results}

The results of the application of the GAD7, PHQ9 and Shirom-Melamed Burnout questionnaires to 1185 parents in the state of Durango are presented below in order to evaluate the incidence of the National School Coexistence Program on the mental health of these actors.

In order to carry out this weighting, the values of the measures of central tendency and dispersion applied were taken, which allowed describing the most notable results of each of the sections that make up the study carried out. 


\begin{tabular}{|c|c|c|c|c|}
\hline Item & & Valı & & \\
\hline & CTD & MMD & VD & $\mathrm{N}$ \\
\hline $\begin{array}{l}\text { During the past } 2 \text { weeks, } \\
\text { how often do you feel } \\
\text { uneasy because you are } \\
\text { worried and cannot } \\
\text { control it? }\end{array}$ & & & & $47 \%$ \\
\hline $\begin{array}{l}\text { During the past } 2 \text { weeks, } \\
\text { how often do you feel } \\
\text { discomfort from } \\
\text { worrying about too } \\
\text { many things at once? }\end{array}$ & & & $49 \%$ & \\
\hline $\begin{array}{l}\text { During the past } 2 \text { weeks, } \\
\text { how often have you } \\
\text { been bothered by: } \\
\text { Difficulty relaxing? }\end{array}$ & & & $43 \%$ & \\
\hline $\begin{array}{l}\text { During the last } 2 \text { weeks, } \\
\text { how often are you able } \\
\text { to relax? }\end{array}$ & & & $41 \%$ & \\
\hline $\begin{array}{l}\text { During the past } 2 \text { weeks, } \\
\text { how often do you feel } \\
\text { restless or anxious that it } \\
\text { is difficult for you to sit } \\
\text { still? }\end{array}$ & & & & $54 \%$ \\
\hline $\begin{array}{l}\text { During the past } 2 \text { weeks, } \\
\text { how often do you } \\
\text { become easily irritable? }\end{array}$ & & & $44 \%$ & \\
\hline $\begin{array}{l}\text { During the last } 2 \text { weeks, } \\
\text { how often do you feel } \\
\text { afraid that something } \\
\text { terrible might happen? }\end{array}$ & & & & $52 \%$ \\
\hline
\end{tabular}

*Values

CTD Almost Every Day

MMD More than half of the days

VD Several Days

N Never

Table 1 Mental Health I GAD-7

Source: Own Elaboration

\section{Mental health I GAD-7}

One of the aspects assessed to the mothers and fathers with the GAD-7 instrument is mental health, integrated by items related to the management of the discomforts that could have been presented and the ability to relax during the 2020-2021 school cycle.

Regarding the emotional well-being of mothers and fathers during the COVID-19 pandemic, according to the results obtained in the GAD-7 and within the framework of the National School Coexistence Program, somewhat opposite results were obtained since, while about $50 \%$ of the respondents never felt discomfort related to worries:
- For not being able to control themselves.

- $\quad$ For not being able to relax.

- Fear that something terrible might happen.

On the other hand, 50\% said that several days of the week they felt discomfort:

- Worrying about too many things at once.

Being restless or anxious to the point of not being able to sit still.

- $\quad$ Being easily irritated.

However, it is also important to mention that $41 \%$ of the cases, several days a week they were able to relax, which leads to the conclusion that in half of the cases they had elements to eliminate emotional tensions.

\begin{tabular}{|l|l|l|l|l|}
\hline \multirow{2}{*}{ Item } & \multicolumn{4}{c|}{ Values* } \\
\cline { 2 - 5 } & My & L & Mo & S \\
\hline Resultats & $12 \%$ & $29 \%$ & $35 \%$ & $24 \%$ \\
\hline
\end{tabular}

$*$ Values

My Minimal

L Mild

Mo Moderate

S Severe

Table 2 GAD-7 Results

Source: Prepared by the authors

GAD-7 Results

Regarding the results found on the mental health of mothers and fathers, with the application of the GAD-7, 50\% did not feel discomfort or worries and at the same time they had elements to eliminate emotional tensions, and $50 \%$ felt moderate discomfort and worries $(35 \%)$ and $24 \%$ felt severe discomfort and worries. 


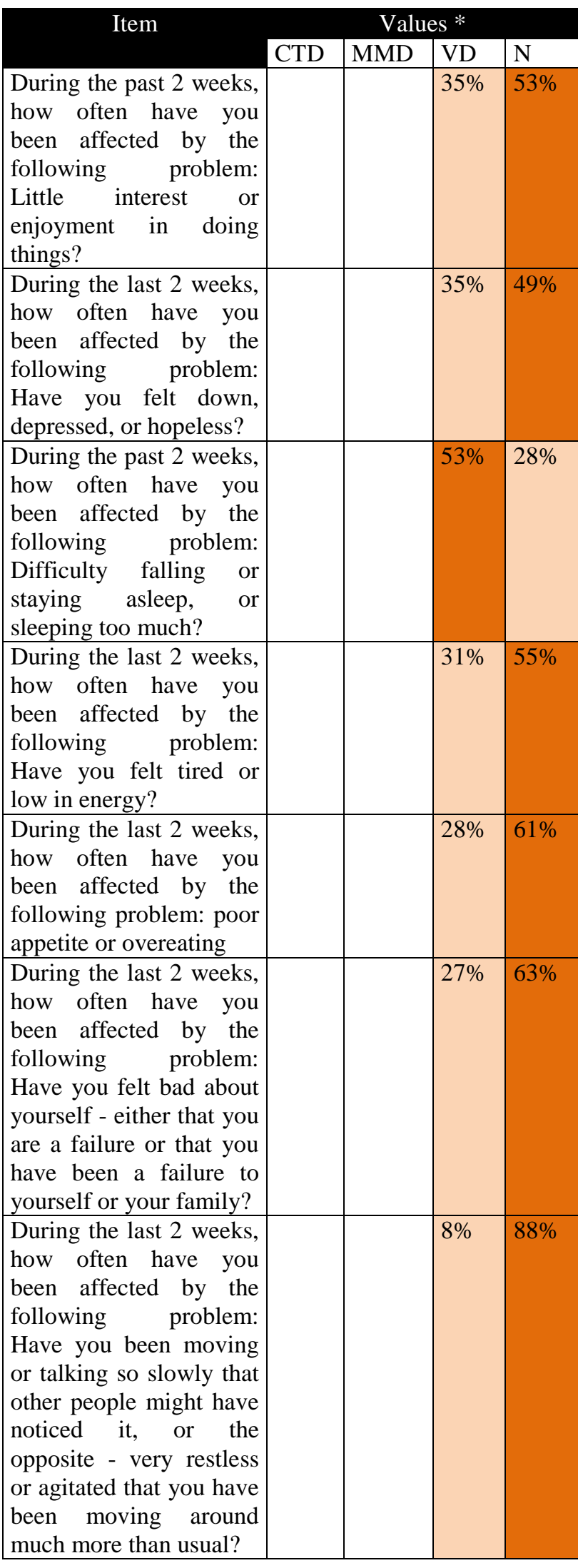

*Values

CTD Almost Every Day

MMD More than half of the days

VD Several Days

N Never

Table 3 Mental health II PHQ9

Source: Own Elaboration

\section{Mental Health II PHQ9}

The second test used to assess the mental health of mothers and fathers is the PHQ9 instrument, composed of items related to personal, interpersonal or contextual problems that may have occurred during the 2020-2021 school year, the period in which the COVID-19 confinement was experienced and in which the National School Coexistence Program was applied in educational institutions.

Statistical processing shows that the participants scored the lowest values on the scale (VD Several Days and N Never), when questioned about the aforementioned problems. As can be seen in Table 3: Mental Health II PHQ9 in most of the indicators, percentages ranging from $49 \%$ to $88 \%$ in the value of the scale "Never" indicate that in these cases on no occasion have they felt affected by any problem, except for the difficulty in falling or staying asleep, or on the contrary sleeping too much several days a week, value of the scale applied, where about $30 \%$ of the respondents state that several days a week they have had the following difficulties:

- Little interest or pleasure in doing things.

Feeling down, depressed or hopeless.

- Feeling tired or low in energy.

- $\quad$ Poor appetite or overeating.

- $\quad$ Feeling of failure, that you have looked bad to yourself or your family.

- To move or talk so slowly that other people may have noticed, or to be so restless or agitated that you have been moving around a lot or more than usual.

\begin{tabular}{|ll|l|l|l|l|}
\hline \multirow{2}{*}{ Ítem } & \multicolumn{4}{c|}{ Values* } \\
& My & L & Mo & MS & S \\
\hline Results & $19 \%$ & $13 \%$ & $19 \%$ & $24 \%$ & $25 \%$ \\
\hline
\end{tabular}

*Values

My Minimal

L Mild

Mo Moderate

MS Moderately Severe

S Severe

Table 4 PHQ9 Results

Source: Own Elaboration 


\section{PHQ9 Results}

The main difficulty found in the parents to whom the PHQ9 questionnaire was applied is related to problems falling or staying asleep, or on the contrary sleeping too much several days a week in $53 \%$ of the cases and, nevertheless, that only one third of the participants state that several days a week they have had the following difficulties:

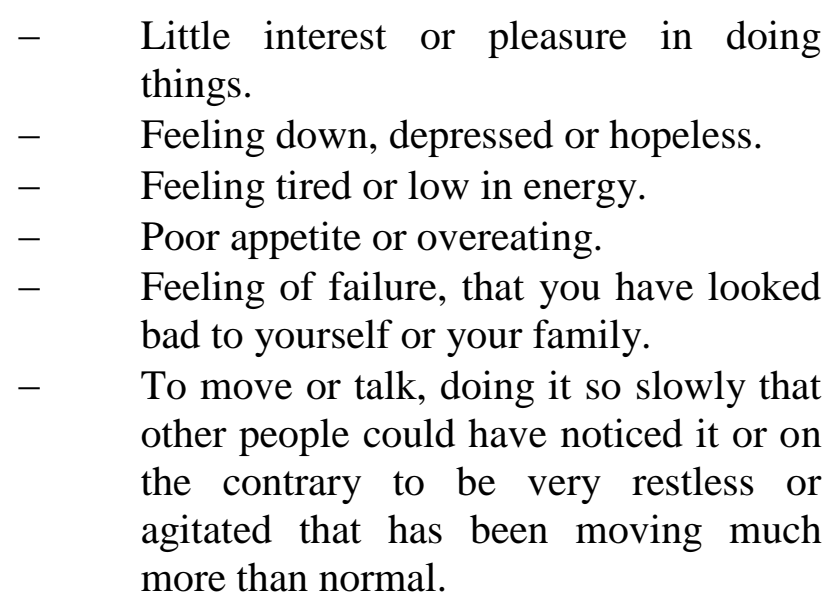

In either case about $50 \%$ consider that when these problems occur it affects them moderately severely or severely.

\begin{tabular}{|c|c|c|c|c|c|c|c|}
\hline \multirow[t]{2}{*}{ Item } & \multicolumn{7}{|c|}{ Values* } \\
\hline & MV & $\mathrm{CS}$ & $\begin{array}{l}\mathrm{M} \\
\mathrm{T}\end{array}$ & BS & AV & PV & $\mathrm{CN}$ \\
\hline Do I feel tired? & & $23 \%$ & & & & $35 \%$ & \\
\hline $\begin{array}{lcc}\text { Do } & \text { I } & \text { feel } \\
\text { energized? } & \end{array}$ & & & & & $17 \%$ & $26 \%$ & \\
\hline $\begin{array}{l}\text { Do I feel physically } \\
\text { fatigued? }\end{array}$ & & & & & $17 \%$ & $29 \%$ & \\
\hline $\begin{array}{l}\text { Do I feel I've had } \\
\text { enough? }\end{array}$ & & & & $27 \%$ & $41 \%$ & & \\
\hline $\begin{array}{l}\text { Do I feel full of } \\
\text { energy? }\end{array}$ & & & & & $18 \%$ & $21 \%$ & \\
\hline $\begin{array}{l}\text { Do I feel out of } \\
\text { energy? }\end{array}$ & & & & & & $31 \%$ & $33 \%$ \\
\hline Do I feel alert? & & $20 \%$ & & & & $18 \%$ & \\
\hline
\end{tabular}

*Values

MV Many times

CS Almost always

MT Half the time

BS Quite often

AV Some of the time

PV A Few Times

CN Almost Never

Table 5 Mental health III BURNOUT

Source: Own Elaboration

\section{Mental Health III BURNOUT}

The third questionnaire applied to the mothers and fathers is the Shirom-Melamed Burnout, which assesses different situations that may affect their emotional well-being.

As can be seen in Table 5: Mental Health III BURNOUT, the percentages reached in each of the values of the scale represent about a third of the participants, highlighting that $64 \%$ of them almost never or rarely felt without energy. With similar percentages they rarely feel tired, with $41 \%$ that several times they have had enough and that they almost always feel tired or on the contrary feel alert.

\section{Analysis and conclusion}

Mental health is the aspect that mothers and fathers were evaluated, with the GAD-7; so that significant data were obtained on the emotional well-being of parental figures, during the 20202021 school cycle, in which educational institutions worked online because of COVID19 and the National School Coexistence Program was applied.

On the one hand, $50 \%$ of those surveyed stated that they felt uneasy several days of the week:

\footnotetext{
- $\quad$ For worrying about too many things at once.

- $\quad$ Being restless or anxious to the point of not being able to sit still.

- $\quad$ Being easily irritated.
}

And, on the other hand, $41 \%$ of the cases, several days a week they were able to relax, which leads to the conclusion that in half of these cases they had elements to eliminate emotional tensions.

Similarly, with the PHQ9 test, it was found that in most of the indicators, percentages ranging from $49 \%$ to $88 \%$ in the value of the scale "Never" were found, which indicates that in these cases on no occasion have they felt affected by any problem, except for the difficulty in falling or staying asleep, or on the contrary sleeping too much, and nevertheless, that only one third of the participants stated that several days a week they had the following difficulties: 
- Little interest or pleasure in doing things.

- $\quad$ Feeling down, depressed or hopeless.

- $\quad$ Feeling tired or low in energy.

- $\quad$ Poor appetite or overeating.

- $\quad$ Feeling of failure, that you have looked bad to yourself or your family.

To move or talk, doing it so slowly that other people could have noticed it or on the contrary to be very restless or agitated that has been moving much more than normal.

In either case about $50 \%$ consider that when these problems occur it affects them moderately severely or severely.

Additionally, with the Shirom-Melamed Burnout test, the percentages reached in each of the values of the scale represent about a third of the participants, highlighting that $64 \%$ of them almost never or rarely felt without energy. With similar percentages they rarely feel tired, with $41 \%$ that several times they have had enough and that they almost always feel tired or on the contrary feel alert.

\section{Proposal}

In this research process, useful knowledge was generated on the emotional wellbeing of parental figures during the 2020-2021 school cycle, a period in which children and adolescents were provided with online education due to the confinement by COVID19 and the National School Coexistence Program was also applied.

Linked to the conclusions obtained, new research possibilities arise with proposals that raise the management of discomforts that help mothers and fathers to eliminate tensions especially in situations such as the following:

- $\quad$ For worrying about too many things at the same time.

- $\quad$ For being restless or anxious to the point of not being able to sit still.

- $\quad$ Being easily irritated.

- $\quad$ Not being able to sleep well.

- Having little interest or pleasure in doing things.

- $\quad$ Feeling down, depressed or hopeless.

- $\quad$ Feeling tired or low energy.

- Having a poor appetite or overeating.
$-$

For having a feeling of failure, that he/she has looked bad to himself/herself or to his/her family.

For moving or talking so slowly that other people may have noticed it or, on the contrary, being very restless or agitated and moving much more than usual.

Likewise, some suggestions for parents are derived, with the purpose of eliminating tensions (Maristas, n/d and Macías, Madariaga, Valle and Zambrano, 2013):

$\begin{array}{ll}- & \text { Perform relaxation exercises. } \\ - & \text { Perform breathing exercises. } \\ \text { - } & \text { Apply positive coping strategies. } \\ \text { - } & \text { Search for spiritual support. }\end{array}$

\section{Acknowledgements}

To the National Program of School Coexistence in Durango for their vision of carrying out the evaluation under the support and design of digital surveys by LARBAS SA de CV Consultants, which guaranteed the protection of personal data of the participants, based on the ARCO rights contained in Article 16, second paragraph of the constitution, which states that everyone has the right to safeguard, access, rectification, cancellation and opposition of their personal information.

\section{References}

Álvarez, V. S., \& Salazar, R. E. (19 de agosto de 2018). Funcionamiento Familiar y Bienestar Psicologico en Adolescentes. . Obtenido de Universidad Cooperativa de Colombia. Facultad de Ciencias de la Salud.: https://repository.ucc.edu.co/bitstream/20.500.1 2494/7842/1/2018_funcionamiento_familiar_bi enestar.pdf

Adelman, H., \& Taylor, L. (2016). Mental health in schools and public health. Public Health Reports., 294-298.

Bolaños, D., \& Stuart, R. A. (2019). La familia y su influencia en la convivencia escolar. Revista Universidad y Sociedad, vol. 11, no. 5., http://scielo.sld.cu/scielo.php?script=sci_arttext \&pid=S2218-36202019000500140. 
Borrows, F., \& Olivares, M. (2006.). Familia y Proceso de Aprendizaje, Prácticas sociales a nivel familiar que tienen relación con el aprendizaje de niños y niñas del nivel preescolar y del primer ciclo básico. Pontifica Universidad Católica de Chile, 143-167.

Caso, L. A., Osuna, M. N., \& Gallegos, M. V. (2019). Estudio de la implementación del Programa Nacional de Convivencia Escolar (PNCE) en una entidad federativa mexicana. . Psicoperspectivas, vol. 18, núm. 1. Pontificia Universidad Católica de Valparaíso, Escuela de Psicología, p.8.

CNEPDS., C. N. (2018). Evaluación de diseño de Programa Nacional de Convivencia Escolar. México, D.F. CONEVALL. , https://www.gob.mx/cms/uploads/attachment/fi le/234137/InformeFinal_S271.pdf.

Chaparro, A. A., Castro-López, N., Mora, O. N. y Medrano, G. V. (2019). Estudio de la implementación del Programa Nacional de Convivencia Escolar (PNCE) en una entidad federativa mexicana. Disponible en: Estudio de la implementación del Programa Nacional de Convivencia Escolar (PNCE) en una entidad federativa mexicana

Díaz, M., García, J., \& Legañoa, M. (2018). Modelo de gestión del acompañamiento pedagógico para maestro de primaria. Transformación., pags. 1-14. Obtenido de http://scielo.sld.cu/scielo.php?script=sci_arttext \&pid=S2077-29552018000100005

DOF., D. O. (15 de diciembre de 2013). Ley General de Educación. Obtenido de http://www.diputados.gob.mx/LeyesBiblio/ref/l ge/LGE_ref26_11sep13.pdf

DOF., D. O. (04 de diciembre de 2017). "Plan Nacional de Desarrollo 2013-2018". Obtenido de

http://dof.gob.mx/nota_detalle.php?codigo $=529$ $9465 \&$ fecha $=20 / 05 / 2013$.

DOF., D. O. (04 de agosto de 2017). Acuerdo número 25/12/17 por el que se emiten las Reglas de la Operación del Programa Nacional de Convivencia Escolar para el ejercicio fiscal 2018. Obtenido de http://normatecainterna.sep.gob.mx/work/model s/normateca/Resource/444/3/images/acuerdo_2 5_12_17s271.pdf
Edel Navarro, R. (2003). El rendimiento académico: concepto, investigación y desarrollo. Revista Iberoamericana sobre Calidad, Eficacia y Cambio en Educación, 1(2).

Faros, S. J. (08 de octubre de 2020). La salud mental de padres y madres durante la pandemia Covid-19 afecta a los hijos. . Obtenido de FAROS. SJD, Barcelona Hospital: https://faros.hsjdbcn.org/es/articulo/saludmental-padres-madres-durante-pandemiacovid-19-afecta-hijos

Feldman, R. (2007). Maternal versus child's risk and the development of parent-infant and family relationships in five high-risk populations. Development and Psychopathology. .

Gere, M., Hagen, C., Villalbo, M., Arnberg, K., Neumer, S., \& Torgensen, S. (2013). Fathers' Mental Health as a protective factor in the relationship between maternal and child depressive symptoms. . Depression and Anxiety., 31-38.

Macías, M. A., Madariaga, O. C., Valle, A. M. y Zambrano, J. (2013) Estrategias de afrontamiento individual y familiar frente a situaciones de estrés psicológico. ISSN: 0123417X. Disponible en: https://www.redalyc.org/pdf/213/21328600007. pdf

Maristas. (s/f). Actividades para reducir el estrés en los niños. Disponible en: https://primaria.colegiomarista.edu.mx/wpcontent/uploads/2020/05/Actividades-parareducir-el-estr\%C3\%A9s-en-losni\%C3\%B1os.pdf

Odalk, F. E., Sánchez, A. J., Aguilar, J., Lojero, R. A., Tenorio, S. V., Sánchez, D. A., . . . Flores, P. L. (2016). Manual para el docente. Educación primaria del Programa Nacional de Convivencia Escolar. Ciudad de México.: D.R. Secretaría de Educación Pública, Argentina 28, Centro. ISBN: 978-607-623-731-1.

OMS, (2004). Invertir en salud mental. ISBN 924356257 6. Disponible en: https://www.who.int/mental_health/advocacy/e n/spanish_final.pdf

OMS, O. M. (2013). Plan de Acción sobre Salud Mental 2013-2020. Suiza: OMS., p.2.

LARA-ESQUEDA, Agustin, CEJAS-LEYVA, Luz María, HERRERAVARGAS, Isela Vanessa and LARA-BASULTO, Agustin David. Mental health and school life in Durango Parents' perspective. Journal Practical Didactics. 2021 
OPA. (15 de agosto de 2021). Reflexiones acerca de salud mental escolar: Una tarea formativa urgente y posible. . Obtenido de Centro OPA.

http://opa.cl/2020/06/04/reflexiones-acerca-desalud-mental-escolar-una-tarea-formativaurgente-y-posible/

PNCE. (17 de agosto de 2021). Subsecretaría de Educación Básica Dirección General de Desarrollo de la Gestión Educativa. Programa Nacional de Convivencia Escolar. . Obtenido de

https://www.gob.mx/cms/uploads/attachment/fi le/195743/DB_PNCE_260217.pdf

Rodrigo, M., Martín, J., Cabrera, E., \& Máiquez, M. (2009). Las competencias Parentales en contextos de riesgo psicosocial. . Intervención Psicosocial.

http://scielo.isciii.es/scielo.php?script=sci_artte xtypid=S1132-

$05592009000200003 \mathrm{yln} g=$ esynrm $=$ iso $>$. ISSN 1132-0559.

SEP., S. d. (04 de febrero de 2017). Informe Nacional lera Fase. Cuestionario sobre percepción de clima en la escuela y habilidades sociales y emocionales ciclo escolar 20162017. . Obtenido de Programa Nacional de Convivencia Escolar. México, D.F. SEP: https://www.gob.mx/cms/uploads/attachment/fi le/262430/RESULTADOS_NACIONALES.pdf

SEP. (2018). Documento base del programa nacional de convivencia escolar para autonomía curricular, ciclo 2018, 2019. CDMX. Disponible en: https://www.gob.mx/cms/uploads/attachment/fi le/414833/Documento_base_del_Programa_Na cional_de_Convivencia_Escolar_para_Autono m_a_Curricular_ciclo_2018_final.docxlo.pdf

SEP. (2019). Programa Nacional de Convivencia Escolar, Informe Nacional de Resultados. CDMX. Disponible en: https://www.septlaxcala.gob.mx/convivencia_e scolar/informe_resultados_pnce_18_19_nacion al.pdf

Serrano Barquín, C., Rojas García, A., \& Ruggero, C. (2013). Depresión, ansiedad y rendimiento académicon en estudiantes universitarios. Revista Intercontinental de Psicología y Educación, 15(1), 47-60.
Serrepe, Z. I. (2015). Propuesta de un programa de inteligencia emocional basado en las relaciones interpersonales, para mejorar la adaptación social de los estudiantes del primer ciclo del instituto de Educación superior tecnológico "Cayetano Heredia".

Treviño, E., Castro, R., Costilla, R., Donoso, P. C., \& Valdés, H. (2010). Factores asociados al logro cognitivo dee los estudiantes de Américca Latina y el Caribe, Santiago: Oficina Regional de Educación de la UNESCO para América Latina y el Caribe. p.15. 